\title{
Reclaiming Diverse Seed Commons Through Food Sovereignty, Agroecology and Economies of Care
}

\author{
Michel Pimbert
}

\begin{abstract}
Seed commons - the collective management of seeds and associated knowledge-is a major aim of food sovereignty, that crucial alternative to the dead end of industrialized agriculture. To reclaim the commons, explains Michel Pimbert in this wide-ranging policy analysis, we need to enable community control over growing, trading and consuming food. That will demand mutually supportive transformations in agriculture, economies, rights and political systems towards agroecology, an economics of solidarity, collective notions of property and direct democracy. Drawing on sources such as the Nyéléni Declaration on food sovereignty and the UN Declaration on the Rights of Peasants and Other People Working in Rural Areas, Pimbert outlines a radical approach to seed governance outside the capitalist and patriarchal paradigm. The proposals, while scarcely featuring in global and national fora on seed
\end{abstract}

M. Pimbert ( $\bowtie)$

Centre for Agroecology, Water and Resilience, Coventry University, Coventry, $\mathrm{UK}$ e-mail: michel.pimbert@coventry.ac.uk

Y. Nishikawa and M. Pimbert (eds.), Seeds for Diversity and Inclusion, https://doi.org/10.1007/978-3-030-89405-4_2 
governance, offer a fresh framework for needed change at a time of social exclusion, poverty and deepening environmental crises.

Keywords Community control · Food sovereignty · Agroecological transformation · Diverse seed commons

\subsection{INTRODUCTION}

Food sovereignty-community control over how food is consumed, traded and produced-offers a normative framework for radically rethinking how seeds are governed and managed. That in turn reveals a way of exiting the dead-end of unsustainable industrial agriculture (IAASTD, 2009; Steffen et al., 2015).

Reclaiming locally controlled and diverse seed commons is an important goal for food sovereignty. Regenerating decentralized forms of governance and management of diverse seed commons can be achieved by emphasizing several dimensions of the food sovereignty paradigm: the agroecological transformation of agri-food systems, the reinvention of an economics of care and conviviality, collective tenure and genderequitable rights to seeds and the wider systems they are embedded in, and a deepening of democracy for social and environmental justice.

These mutually supportive transformations seek to put seeds and the food systems they are part of outside capitalism and patriarchy. This is the main argument presented in this chapter.

\subsection{Food Sovereignty ANd Seeds}

Food sovereignty aims to recreate the realm of democracy and freedom by fostering the regeneration of diverse autonomous food systems in both rural and urban areas (Pimbert, 2008). It is thus grounded in the idea that farmers and other citizens-men and women-can and should govern themselves by engaging in the practice of democracy. The Declaration of the 2007 Nyéléni Forum on Food Sovereignty affirms the centrality and primacy of "peoples" in framing policies and practices for food, agriculture, environment and human wellbeing: 
Food sovereignty is the right of peoples to healthy and culturally appropriate food produced through ecologically sound and sustainable methods, and their right to define their own food and agriculture systems. It puts those who produce, distribute and consume food at the heart of food systems and policies rather than the demands of markets and corporations. It defends the interests and inclusion of the next generation. It offers a strategy to resist and dismantle the current corporate trade and food regime, and directions for food, farming, pastoral and fisheries systems determined by local producers. Food sovereignty prioritizes local and national economies and markets and empowers peasant and family farmer-driven agriculture, artisanal fishing, pastoralist-led grazing, and food production, distribution and consumption based on environmental, social and economic sustainability. Food sovereignty promotes transparent trade that guarantees just incomes to all peoples as well as the rights of consumers to control their food and nutrition. It ensures that the rights to use and manage lands, territories, waters, seeds, livestock and biodiversity are in the hands of those of us who produce food. Food sovereignty implies new social relations free of oppression and inequality between men and women, peoples, racial groups, social and economic classes and generations. (Nyéléni, 2007)

Over the past two decades, food sovereignty has been discussed and defended under the leadership of La Vía Campesina ${ }^{1}$ (Desmarais \& Nicholson, 2013; Pimbert, 2019). Other social movements have also contributed to shaping the agenda around this issue. Most notably, Indigenous peoples have expanded the food sovereignty paradigm to include sacred and spiritual dimensions of life. For example, members of the Indigenous Circle during Food Secure Canada's People's Food Policy process ${ }^{2}$ broadened the food sovereignty framework by emphasizing: "Food is sacred — food is a gift of life, not to be squandered. It cannot be commodified". While keeping within the conceptual framing

${ }^{1}$ The term food sovereignty was first brought to international attention at the World Food Summit organized by the Food and Agriculture Organization of the United Nations in 1996. It was put forward by La Vía Campesina, an international movement that coordinates organizations of small- and medium-sized producers, agricultural workers, rural women and Indigenous communities from Asia, the Americas and Europe. During the 1996 World Food Summit, La Vía Campesina presented a set of mutually supportive principles as an alternative to the world trade policies and to realize the human right to food. In their statement, Food sovereignty: a future without hunger (1996), they declared: "Food sovereignty is a precondition to genuine food security".

2 See https://foodsecurecanada.org. 
developed by La Vía Campesina, Indigenous peoples also tend to emphasize food sovereignty as a right for Indigenous peoples to choose, to cultivate and to preserve their food practices and endogenous biocultural values (FAO, 2021).

Caring for the diversity of cultivated and wild plant seeds lies at the heart of food sovereignty and autonomous food systems (Pimbert, 2008). In this sense, seed sovereignty is about Indigenous peoples, peasant farmers, seed keepers, forest dwellers and other food producers having the capacity and right to save, grow, sell and share their seeds. It refers to the fundamental right of people "to breed and exchange diverse open source seeds which can be saved and which are not patented, genetically modified, owned or controlled by emerging seed giants". ${ }^{3}$

\subsection{ReinVenting Modernity for Diverse Seed Commons}

For food sovereignty advocates, ideas about seeds need to be liberated from today's dominant vision of modernity and the corporate enclosure of the commons. Reinventing modernity is necessary as a way of exiting capitalism, and to enable a diversity of place-specific seed commons for autonomy and endogenous development.

Throughout the world, peoples - especially youth — are affirming other visions on how to live with, and care for, diverse seeds and the land. Their pluralistic visions of modernity increasingly reject the commodification of nature and social relations (Rist, 2013) and focus on the creation and maintenance of "the good life"-concepts and practices such as buen vivir or sumak kausai in Latin America, ecological swaraj in India (Kothari et al., 2014) de-growth in Europe (D'Alisa et al., 2014; Latouche, 2011) and feminist subsistence perspectives (Mies \& Bennholdt Thomsen, 1999). In this reimagined pluriverse (Kothari et al., 2019), ideas, discourses and practices reconnect individuals with nature and help rebuild strong communities embedded in specific ecosystems and their diverse seed commons.

In practice, regenerating seed commons partly depends on respectfully relating to seeds as sisters, mothers and living sentient beings rather

\footnotetext{
3 See PBS feature The Lexicon of Sustainability https://www.pbs.org/food/features/ lexicon-of-sustainability-seeds/.
} 
than anonymous, inert commodities. It is noteworthy that despite the dominant narrative, which treats seeds as a mere input for farming, many Indigenous, pastoral and peasant societies continue to nurture seeds as members of their own family or as part of the larger sacred world of the Pachamama (Mother Earth) in South America (Chapter 4), or Buthali in South Asia (Community Media Trust et al., 2008). Seeds are seen as not only having a soul and identity in many of these societies; they also embody the indivisibility of nature and culture. During seed festivals such as the Watunakuy, Andean indigenous communities bless and celebrate their seeds through their songs and mantras. ${ }^{4}$ They know from experience that if seeds are not honoured, loved and deeply cared for, then crops planted from them will be disease-prone and will not yield good harvests. Peoples' expressions of love and care for local seeds thus mediate subtle agroecologies - a process Western science is only beginning to understand (Wright, 2021).

Regenerating seed commons also depends on protection from private enclosure; collective, polycentric management; sharing of formal and practical knowledge; and collective responsibility (Sievers-Glotzbach et al., 2020, 2021). "Seed commons" are commoning-based arrangements centred on seeds, in which a community conducts de facto handling, growing, breeding and sharing of seeds (Sievers-Glotzbach et al., 2020; and see Chapter 12). In effect, the seed commons is made by commoning (Boiler \& Helfrich, 2019; Ruivenkamp \& Hilton, 2017).

Within the framework of food sovereignty, seed commoning is part of the day-to-day activities mediated by local organizations that serve different purposes within communities (Pimbert, 2008, 2018a ), such as:

- sustaining the ecological basis of agri-food systems-including producing knowledge and joint actions for the local adaptive management of land, seeds and water, as well as the development of reliable bio-physical indicators to track and respond to change, including climate change;

- coordinating human skills, knowledge and labour to generate both use values and exchange values in the economy of the agri-food system, as well as organize economic exchanges within and between territories;

${ }^{4}$ Mujumama, or Mother Seed. See https://vimeo.com/565544165. 
- governing agri-food systems-including polycentric and placespecific decisions about people's access to food and natural resources (such as land and seeds) as well as collectively generating the political knowledge needed to shape policies and institutions.

Several local organizations with different functions, powers and responsibilities are usually needed to coordinate different seed commoning activities (see Chapter 12). Such "nested organizations" operate at different scales and act in complementary ways. These interlinked organizations and networks provide the institutional landscape that is needed to manage dynamic complexity in the social and ecological realms in which seeds and food systems are embedded.

This polycentric web of interacting organizations provides the basis for decentralized governance, and autonomous seed and food systems (Pimbert, 2008). It also helps keep seeds in farmers' hands and maintains the high diversity of cultivated and wild seed plants needed to build agroecology-based agri-food systems that are resilient to climate change, pandemics and market volatility.

\subsection{How Agroecology Sustains Seed Diversity}

Rooted in local Indigenous and peasant knowledge and the science of ecology and complexity, agroecological practices are reliant on high seed diversity: multi-species polycultures, intercrops, agroforestry, genetic mixtures, mixed farming and agro-sylvo-pastoral systems (Altieri, 1995; Gliessman, 2015). Agroecology also works to diversify the ecosystems and landscapes in which farming systems are embedded (Pimbert et al., 2021).

For example, in the "forest home gardens" that cover 15\% of the land in Sri Lanka, family farmers raise trees, shrubs, herbs, crops and animals in a complex multi-layered agroecological system. The garden system mimics and merges with the complex structure and multiple functions of a forest, although it is not identical to it. A diversity of cultivated and edible wild seed plants are combined at multiple scales to yield many benefits, including resilience to climatic shocks and stresses as well as healthy nutrition in a diverse array of fruits, vegetables, spices and medicines, fodder and staple food items (Pushpakumara et al., 2012).

Worldwide, people and nature have co-created complex, multi-layered agroecologies based on cultivated and non-cultivated seeds. While research and policy mostly focus on crop seeds, wild and semi-wild seed 
plants continue to be key for "society-nature co-evolution" (Norgaard \& Sikor, 1995), ecological sustainability and food and livelihood security (Gujit et al., 1995). For example, agricultural and forager communities in 22 Asian and African countries (as shown by 36 studies) use an average of 90-100 species. In Ethiopia, India and Kenya, aggregate country estimates can reach 300-800 species (Bharucha \& Pretty, 2010; Gujit et al., 1995).

In India, women Dalit farmers in the Medak district of Telangana eat more than 40 species of highly nutritious wild greens in different seasons. The diets of these dryland farmers include 329 species or varieties of cereals, millets, oil seeds, pulses, fruit, vegetables, wild greens, roots and tubers. Seeds, roots, leaves, flowers, fruits, gums and bark are also consumed seasonally. Knowledgeable non-literate women farmers nurture the seeds of these highly nutritious wild foods in environments they have co-created with nature: collectively managed watersheds, common lands, tree plantations and woodlands, field edges and organically manured farm plots (Salomeyesudas \& Satheesh, 2009). As "spiritual caretakers and cocreators of the Maya forest" (Ford \& Nigh, 2015) in Central America, Maya farmers nurture diverse seed commons through their milpa system, a perennial multi-cropping and multi-stage cyclical agriculture and agroforestry system based on maize and at least 90 other Mesoamerican plants.

Such Indigenous and peasant land-use practices create mosaics of agricultural areas and patches of wild biodiversity at multiple scales (Perfecto \& Vandermeer, 2017). This "natural matrix" model sustains a variety of habitats and micro-environments as well as a diversity of cultivated and wild species (such as flowering seed plants, insects, birds and mammals), many of which are edible and often key for the provision of ecosystem functions such as pollination. These territories conserve a huge diversity of cultivated and wild seed plants (see Chapter 4), and are de facto governed by Indigenous and local communities who derive livelihoods from them (Pimbert \& Borrini-Feyerabend, 2019). When guided by a feminist ethics of care, new agroecological ways of organizing can emerge within these territories of life, as suggested by practices in southern Mexico (Lilia et al., 2020) and decolonial feminist movements (Milgroom, 2021).

Re-localizing an agri-food system within a specific territory can significantly enhance possibilities for using a greater diversity of cultivated and wild seed plants that are adapted to the many heterogenous environments 
created through agroecological practices-from micro-environments to larger landscapes, as well as new economic niches along food chains. This is one of the reasons why food sovereignty approaches lead to the development of agri-food networks that re-localize agroecological production, processing, distribution, consumption and waste recycling within territories.

Such agroecological diversification and re-localization of agri-food systems within territories demands unrestricted access to high levels of inter- and intra-specific seed diversity. High levels of genetic heterogeneity within and between species enable adaptation to a rich mosaic of placespecific social and environmental conditions. Through this, the uniformity of industrial monocultures can be reversed, and replaced by increasing diversity, micro-geographical differentiation, dynamic local adaptation and a self-organizing ecological complexity. Such agroecological regeneration of seed diversity can be observed in the evolutionary plant breeding of cereals and other crops in Iran and Italy (see Chapter 8), where crop populations with high genetic diversity are grown in ways that encourage adaptation to the environment.

Similarly, seed diversity is often enhanced within territories through agroecological farming and decentralized food webs that closely link farmers with artisan producers and local markets for new productssuch as the flour, bread and beer made from Hebridean rye in Scotland (Chapter 9; see also CSM, 2016).

The shift from industrial uniformity to living diversity is further enabled by a transformative agroecology that restructures and reterritorializes food and fibre production, distribution and consumption within decentralized circular systems that mimic natural ecosystems at different scales- - from individual farm plots to entire cities. This re-territorializing of agri-food systems echoes the proposals of the Russian anarchist geographer Peter Kropotkin (1898) for an agrarianindustrial mutualism, in which most economic activities are re-localized in villages mixing agricultural and industrial elements, where production is controlled by those directly engaged in it. Kropotkin's ideas on how to overcome the spatial inefficiencies of capitalist production and generate synergies between small-scale industry and agriculture are particularly relevant today. For example, they might be applied to the design of shorter supply chains that are less vulnerable than global value chains to the massive disruptions caused by pandemics (UNEP, 2020). 
The building blocks for circular systems based on an agrarian-industrial mutualism do exist, and include enhancing functional biodiversity, ecological clustering of industries, recycling, and localized production and consumption in specific rural and urban territories (Jones et al., 2012; Isenhour \& Reno, 2019; Pimbert, 2012). Circular systems that combine food and energy production with water and waste management not only increase the use of seed diversity over time and space. They can also reduce greenhouse-gas emissions as well as ecological and material footprints, while maintaining a good quality of life through controlled processes of de-growth in consumption and production. ${ }^{5}$

More generally, agroecological pathways to sustainability can help reclaim the seed commons by using a wide diversity of heterogeneous cultivated and wild seeds in agri-food systems and the environments they are embedded in. Decentralized and re-territorialized agroecological systems using a large diversity of heterogeneous seeds (cultivated and wild plants) are usually more resilient to shocks and stresses, including climate change and market volatility. ${ }^{6}$

However, reclaiming a diversity of seed commons through agroecology demands a system-wide change in which seed management and governance are part of a larger paradigm shift towards food sovereignty. Such large-scale agroecological transformations depend on more inclusive democracy and justice in six key domains: access to natural ecosystems, including land, water and seeds; systems of economic exchange and markets; knowledge and culture; social networks and local organizations; discourses; and equity, gender and diversity (Anderson et al., 2021).

Within each of these domains exist structures and processes that constrain agroecology, and others that enable it. Different means are deployed by specific actors, such as agri-business and civil society organizations, to ensure that agroecology either "fits and conforms" or "stretches and transforms" the dominant agri-food regime (Levidow et al., 2014). This is a highly charged political process that

5 Such as those encapsulated in the eight "Rs": re-evaluate, re-conceptualize, restructure, redistribute, re-localize, reduce, reuse and recycle (Latouche, 2011).

6 The resilience of such biodiversity-rich agri-food systems emerges from internal processes of functional diversity and redundancy, self-regulation, connectivity, response diversity, space and time heterogeneity, the building of natural assets such as soil fertility, social self-organization, reflective learning, autonomy and local interdependency (Tittonell, 2020). 
creates major controversies and power conflicts at local, national and global levels (Anderson et al., 2021; Pimbert, 2018b).

\subsection{Reinventing an Economics of Care}

From a food sovereignty perspective, a central challenge for seed governance and management is to claim, recover and implement economic processes that support community control over seeds, knowledge and the means of livelihoods. Two interrelated issues are key in this context.

\subsubsection{Access to Land, Seeds, Water and Other Means of Production}

Colonial powers, agri-business corporations, conservation organizations and national governments: all have a history of appropriating seeds, land and natural resources, and denying the pre-existing rights of Indigenous peoples and peasant communities. Mutualities of care and community solidarity are eroded as the subsistence economy of the commons is transformed into marketable "goods and services" by private enterprises that organize wage labour to meet "consumer demand" (Illich, 2005).

In response to these enclosures, food and seed sovereignty activists have defined, demanded and defended access to land, seeds, water and other means of production as a human right, and important international instruments and agreements have been achieved in the last three decades (Claeys, 2015; Golay \& Bessa, 2019; Pimbert \& Borrini-Feyerabend, 2019). The United Nations Declaration on the Rights of Peasants and Other People Working in Rural Areas (UNDROP) ${ }^{7}$ is the most recent UN instrument that recognizes new human rights. These include the right to land, seeds, natural resources and food sovereignty via agroecology, local markets, local seeds, participatory decision-making, gender justice and the transition to resilient and sustainable food systems (La Vía Campesina, 2020).

Ensuring that governments enforce and protect the collective and individual rights enshrined in UNDROP, along with other international instruments and declarations, depends on the agency and collective action of peoples and communities. In the interests of equity and nondiscrimination, food and seed sovereignty movements must focus on securing collective rights and promote at all levels the equitable resolution of power dynamics related to gender, wealth, age, disability, ethnic

7 The UNDROP was approved by the UN General Assembly in December 2018. It is available at http://ap.ohchr.org/documents/dpage_e.aspx?si=A/HRC/39/L.16. 
background and other axes of difference (Claeys and Bourke Martignoni, 2021).

\subsubsection{Diverse Economies of Care for Diverse Seeds}

From a food sovereignty perspective, many custodians of diverse seed commons need their own distinct forms of economic exchange that minimize the need to participate in global commodity markets. In essence, they need diverse economies to sustain their unique seed commons and autonomous food systems.

Fortunately, "more-than-capitalist economies" (Gibson-Graham \& Dombroski, 2020) persist across the world. In fact, much of the world's economy is informal, cooperative, hidden, community-based and unwaged (Rist, 2011; White \& Williams, 2014). Empirical examples from economic geography show how diverse economies can also include more than human labour and human/non-human interdependence (GibsonGraham \& Dombroski, 2020). Although they are ignored, devalued and undermined by mainstream economic theory, these forms of economic organization offer relevant models for food and seed sovereignty.

For example, local control over seed saving and seed sharing is usually stronger in economies that combine market activities with non-monetary forms of exchange based on barter, reciprocity, gift relations, care and solidarity (Chapter 4; Argumedo \& Pimbert, 2010). Such complementary forms of local economic exchange offer alternatives to markets solely focused on money. But to advance seed sovereignty and enable a diversity of seed commons, such plural forms of economic exchange must be acknowledged, developed and strengthened.

More fundamentally, if diverse seed commons are to be defended and food and seed sovereignty supported, a radical rethink of economics is needed. Some further ideas that could enable a post-capitalist and postpatriarchal economics include:

- a guaranteed and unconditional minimum income for all men and women

- a significant drop in time spent in wage-work and a fairer sharing of jobs and free time between men and women

- wealth redistribution measures-taxing the hyper-rich and corporations as well as financial speculations to free up resources for poorer 
social groups and regions, and also regenerate local ecologies and economies

- the use of alternative local currencies to retain wealth in reterritorialized economies

- a general and progressive shift to an economics of social inclusion, freedom and solidarity-based on the principle of "from each according to his/her means, to each according to his/her needs"

- economic indicators that reflect and reinforce new definitions of wellbeing such as conviviality, mutual care and frugal abundance.

Practices for diverse economies and autonomy seek to combine these processes in mutually reinforcing ways as part of what Gibson-Graham call the "generative commons" (in de Peuter \& Dyer Witheford, 2010: $46)$.

\subsection{Deepening Democracy}

Food and seed sovereignty movements seek to reverse the democratic deficit and exclusion that favour the interests of powerful corporations, investors, big farmers and technocratic research institutes. But to complement, or replace, the models of representative democracy that prevail in policymaking, "direct democracy" is often needed-that is, the direct participation of citizens in democratic decision-making. This approach is democracy in its original sense, as self-governance: people deciding their individual and collective futures.

A transition to direct democracy poses major challenges. First, deepening democracy assumes that every person is competent and reasonable enough to participate in democratic politics. It also demands a shift in mindset and behaviour from that of passive taxpayers and voters. Second, active citizenship and participation in decision-making are rights that have to be claimed mainly through the agency and actions of people themselves; they are rarely granted by the state or the market.

Third, empowering Indigenous peoples, peasant farmers and other citizens in the governance of seeds and food systems, and stewardship of the ecosystems they are embedded in (such as grasslands, forests and wetlands), demands social innovations that create inclusive and safe spaces for peoples' deliberation and action; build local organizations, horizontal networks and federations to enhance peoples' capacity for voice and agency; strengthen civil society as well as gender and intersectional 
equity; and expand information democracy and citizen-controlled media (community radio and video film-making). Other such needed innovations would promote self-management structures at the workplace and democracy in households; encourage learning from the history of direct democracy; and nurture active citizenship (Pimbert, 2008).

Fourth among the challenges to a shift to direct democracy is that only with some material security and free time can men and women be "empowered" to think about the policies and institutions they want and how they can develop them. Free time is needed for people to fully engage in, and regularly practise, the art of participatory direct democracy. That demands radical reforms in economic arrangements like those listed in Sect. 2.5.2. Not least, deepening democracy in the governance of seeds and agri-food systems also implies greater gender justice outside of patriarchy:

If we do not eradicate violence towards women within the movement, we will not advance in our struggles, and if we do not create new gender relations, we will not be able to build a new society. (La Vía Campesina, 2008)

Forms of people-centred food systems and seed autonomy-seed commons, fruit tree gardens, diverse agroecologies, re-territorialized food systems that re-embed economics in society (cf. Polanyi, 1957)—demand inclusive participation. They also require collective action to coordinate local adaptive management and governance across a wide range of food systems and associated landscapes (farmlands, forests, grasslands and beyond). So to put people at the centre of food systems and to foster seed autonomy, it is key to decentralize and re-distribute power in polycentric and horizontal webs, both in and between territories (Pimbert \& Borrini-Feyerabend, 2019).

One option is democratic confederalism. This system involves a network of bodies or councils made up of citizens, with members or delegates chosen by sortition (selection as a random sample) or elected from face-to-face democratic assemblies in villages, towns and neighbourhoods of large cities (Bookchin, 2015; Öcalan, 2011). The larger and more numerous the linked federations and confederations become, the greater is their potential to democratize and decentralize the governance of food systems and their diverse agroecologies (Pimbert, 2021).

Federating and building alliances between spaces of self-governance and bottom-up decision-making has key potential for the democratic 
governance of seeds and the agri-food systems they are embedded in. However, urgent issues such as the climate crisis also demands engagement with national governments. That suggests a two-pronged approach:

- acting to transform the organizational structures, professional culture and practices of state governance, and a focus on enabling national and municipal governments to support bottom-up, decentralized, multi-ethnic and participatory decision-making. Such transformations demand decisive public intervention by states to limit the disproportionate power of a handful of corporations in the governance of seeds (Clapp, 2021) and the global food system (Canfield et al., 2021).

- strengthening community self-governance and management, developing grassroots horizontal networks and insisting on participatory planning, deliberative and gender inclusive processes for policy making, participatory budgeting, power-equalizing action-research and the co-creation of new knowledge. Expanding community autonomy in governing and managing the commons also depends on enabling mutual aid, collective action, and cooperation through critical popular education (Pimbert, 2018a).

\subsection{CONCLUSION}

The proposals made here are largely absent from global and national discussions on the governance and management of seeds. In fact, many policy and scientific "experts" who are locked into "business as usual" thinking about the Fourth Industrial Revolution for food and farming (WEF, 2018; UNFSS, 2021; and see Introduction, Section 1.4) would say that these are utopian ideas that pose risks to economic progress and private property. However, given the unprecedented existential threats humanity now faces beyond the climate crisis-such as serious biodiversity loss, deepening poverty and massive social exclusion-radical ideas outside capitalism and patriarchy are needed to reimagine and transform seed and food systems for social and environmental justice.

In this regard, the food sovereignty paradigm - with its emphasis on a transformative agroecology, the commons, direct democracy and an economics of care and solidarity-offers hope, and a framework for action. 


\section{REFERENCES}

Altieri, M. A. (1995). Agroecology: The science of sustainable agriculture. Westview Press.

Anderson, C. R., Bruil, J., Chappell, M. J., Kiss, C., \& Pimbert, M. P. (2021). Agroecology now! Transformations towards more just and sustainable food systems. Palgrave Macmillan. https://link.springer.com/book/10.1007/9783-030-61315-0

Argumedo, A., \& Pimbert, M. P. (2010). Bypassing globalization: Barter markets as a new Indigenous economy in Peru. Development, 53(3), 343-349. https://doi.org/10.1057/dev.2010.43

Bharucha, Z., \& Pretty, J. (2010). The roles and values of wild foods in agricultural systems. Philosophical Transactions of the Royal Society B, Biological Sciences, 365(1554), 2913-26. http://rstb.royalsocietypublishing.org/ content/royptb/365/1554/2913.full.pdf

Boiler, D., \& Helfrich, S. (2019). Free, fair, and alive: The insurgent power of the commons. New Society Publishers.

Bookchin, M. (2015). The next revolution: Popular assemblies and the promise of direct democracy. Verso.

Canfield, M., Anderson, M. D., \& McMichael, P. (2021). UN Food Systems Summit 2021: Dismantling democracy and resetting corporate control of food systems. Frontiers in Sustainable Food Systems. https://doi.org/10.3389/ fsufs.2021.661552

Claeys, P. (2015). Human rights and the food sovereignty movement: Reclaiming control. Routledge.

Claeys, P., \& Bourke Martignoni, J. (2021). Women are Peasants Too: Gender equality and the UN declaration on the rights of peasants. Policy brief. Coventry: CAWR. https://www.coventry.ac.uk/globalassets/media/global/ 08-new-research-section/cawr/cawr-policy-briefs/women-are-peasants-toopolicy-brief---14-12-21.pdf

Clapp, J. (2021). The problem with growing corporate concentration and power in the global food system. Nature Food. https://doi.org/10.1038/s43016021-00297-7

Community Media Trust, Satheesh, P. V., \& Pimbert, M. P. (2008). Affirming life and diversity: Rural images and voices on food sovereignty in South India. IIED.

CSM. (2016). Connecting smallholders to markets: An analytical guide. Civil Society and Indigenous Peoples' Mechanism. Retrieved July 20, 2021, from https://www.csm4cfs.org/connecting-smallholders-markets-analytical-guide/

D'Alisa, G., Demaria, F., \& Kallis, G. (2014). Degrowth: A vocabulary for a new era. Routledge.

de Peuter, G., \& Dyer-Witheford, N. (2010). Commons and cooperatives. Affinities: A Journal of Radical Theory, Culture and Action, 4(1): 30-56. 
Desmarais, A. A., \& Nicholson, P. (2013). La Vía Campesina: An historical and political analysis. In La Via Campesina's open book: Celebrating 20 years of struggle and hope. Retrieved July 19, 2021, from https://viacampesina.org/ en/la-via-campesina-s-open-book-celebrating-20-years-of-struggle-and-hope/

FAO. (2021). The White/Wiphala Paper on indigenous peoples' food systems. FAO. https://doi.org/10.4060/cb4932en

Ford, A., \& Nigh, R. (2015). The Maya forest garden: Eight millennia of sustainable cultivation of the tropical woodlands. Routledge.

Gibson-Graham, J. K., \& Dombroski, K. (2020). The handbook of diverse economies. Edward Elgar Publishing.

Gliessman, S. R. (2015). Agroecology: The ecology of sustainable food systems. CRC Press.

Golay, C., \& Bessa, A. (2019). The right to seeds in Europe: The United Nations declaration on the rights of peasants and other people working in rural areas and the protection of the right to seeds in Europe (Briefing No. 15). Geneva Academy of International Humanitarian Law and Human Rights.

Gujit, I., Hinchcliffe, F., Melnek, M., Bishop, J., Eaton, D., Pimbert, M. P., Pretty, J., \& Scoones, I. (1995). The hidden harvest: The value of wild resources in agricultural systems. IIED.

IAASTD. (2009). Agriculture at a crossroads: Synthesis report. UNEP.

Illich, I. (2005). Le silence fait partie des communaux. Le Miroir du passé. Oeuvres Complètes (Vol. 2). Fayard.

Isenhour, C., \& Reno, J. (2019). On materiality and meaning: Ethnographic engagements with reuse, repair \& care. Worldwide Waste: Journal of Interdisciplinary Studies, 2(1), 1-8. https://doi.org/10.5334/wwwj.27

Jones, A., Pimbert, M. P., \& Jiggins, J. (2012). Virtuous circles: Values, systems, sustainability. IIED and IUCN CEESP.

Kothari, A., Demaria, F., \& Acosta, A. (2014). Buen Vivir, degrowth and ecological Swaraj: Alternatives to sustainable development and the green economy. Development, 57(3-4), 362-375. https://doi.org/10.1057/dev.2015.24

Kothari, A., Salleh, A., Escobar, A., Demaria, F., \& Acosta, A. (2019). Pluriverse: A post-development dictionary. Tulika Books.

Kropotkin, P. A. (1898, revised 1913). Fields, factories, and workshops, or industry combined with agricultures and brain work with manual work. Benjamin Blom.

La Vía Campesina. (2008). Declaration of Maputo: V International Conference of La Via Campesina. Retrieved July 19, 2021, from https://viacampesina.org/ en/declaration-of-maputo-v-international-conference-of-la-via-campesina/

La Vía Campesina. (2020). The United Nations declaration on the rights of peasants and other people working in rural areas. La Via Campesina. Retrieved July 19, 2021, from https://viacampesina.org/en/the-united-nations-declarationon-the-rights-of-peasants-a-tool-in-the-struggle-for-our-common-future / 
Latouche, S. (2011). Vers une société d'abondance frugale: contresens et controverses sur la décroissance [Towards a society of frugal abundance: Misinterpretations and controversies about de-growth]. Fayard/Mille et une nuits.

Levidow, L., Pimbert, M. P., \& Vanloqueren, G. (2014). Agroecological research: Conforming - or transforming the dominant agro-food regime? Agroecology and Sustainable Food Systems, 38(10), 1127-1155. https://doi. org/10.1080/21683565.2014.951459

Lilia, D., Espinal, T., \& Peña Azcona, I. (2020). Care ethics in agroecology research: Practices from southern Mexico. Farming Matters, 24-27. Retrieved July 19, 2021, from http://www.cultivatecollective.org/in-practice/farmingmatters-agroecology-feminism/

Mies, M., \& Bennholdt Thomsen, V. (1999). The subsistence perspective: Beyond the globalised economy. Zed Books.

Milgroom, J. (2021). Linking food and feminisms: Learning from decolonial movement. In Agroecology in Motion. Retrieved July 8, 2021, from https:// www.agroecologynow.com/linking-food-and-feminisms/

Norgaard, R. B., \& Sikor, T. O. (1995). The methodology and practice of agroecology. In M. A. Altieri (Ed.), Agroecology: The science of sustainable agriculture. Westview Press.

Nyéléni (2007). Declaration of the forum for food sovereignty, Nyéléni. Retrieved December 23, 2015, from https://nyeleni.org/spip.php?article290

Öcalan, A. (2011). Democratic confederalism. Transmedia Publishing.

Perfecto, I., \& Vandermeer, J. (2017). A landscape approach to integrating food production and conservation. In I. J. Gordon, H. H. T. Prins \& G. R. Squire (Eds.), Food production and nature conservation: Conflicts and solutions. Routledge.

Pimbert, M. P. (2008). Towards food sovereignty: Reclaiming autonomous food systems. IIED and RCC. Retrieved July 20, 2021, from http://www.env ironmentandsociety.org/ $\mathrm{mml} /$ towards-food-sovereignty-reclaiming-autono mous-food-systems

Pimbert, M. P. (2012). Fair and sustainable food systems: From vicious cycles to virtuous circles. IIED Policy Brief, International Institute for Environment and Development, London.

Pimbert, M. P. (2018a). Food sovereignty, agroecology, and bio-cultural diversity: Constructing and contesting knowledge. Routledge.

Pimbert, M. P. (2018b). Global status of agroecology, a perspective on current practices, potential and challenges. Economic and Political Weekly, 53(41), $52-57$.

Pimbert, M. P. (2019). Food sovereignty. In P. Ferranti, E. M. Berry, \& J. R. Anderson (Eds.), Encyclopedia of food security and sustainability (Vol. 3, pp. 181-189). Elsevier. 
Pimbert, M. P. (2021). Regenerating Kurdish ecologies through food sovereignty, agroecology and economies of care. In S. Hunt (Ed.), Ecological solidarity in the Kurdish freedom movement. Lexington Books.

Pimbert, M. P., \& Borrini-Feyerabend, G. (2019). Nourishing life: Territories of life and food sovereignty. Policy Brief of the ICCA Consortium no. 6. Teheran: ICCA Consortium, Centre for Agroecology, Water and Resilience at Coventry University and CENESTA. Retrieved September 18, 2020, from https://www.coventry.ac.uk/globalassets/media/documents/research-doc uments/research-projects/consortium-policy-brief-6-territories-of-life-andfood-sovereignty.pdf

Pimbert, M. P., Moeller, N. I., Singh, J., \& Anderson, C. A. (2021). Agroecology. In M. Aldenderfer (Ed.), Oxford research encyclopaedia of anthropology. Oxford University Press. https://doi.org/10.1093/acrefore/978019 0854584.013 .298

Polanyi, K. (1957). The great transformation. Beacon Press.

Pushpakumara, D., Marambe, B., Silva, P., Weerahewa, J., \& Punyawardena, B. (2012). A review of research on homegardens in Sri lanka: The status, importance and future perspective. Tropical Agriculturist, 160, 55-125.

Rist, G. (2011). The delusions of economics: The misguided certainties of a hazardous science. Zed Books.

Rist, G. (2013). Le développement: histoire d'une croyance occidentale [Development: History of a western belief] (4th revised ed.). Presses de Sciences Po.

Ruivenkamp, G., \& Hilton, A. (2017). Perspectives on communing: Autonomist principles and practices. Zed Books.

Salomeyesudas, B., \& Satheesh, P. V. (2009). Traditional food system of Dalit in Zaheerabad Region, Medak District, Andhra Pradesh, India. In H. V. Kuhnlein et al. (Eds.), Indigenous peoples' food systems: The many dimensions of culture, diversity and environment for nutrition and health. FAO.

Sievers-Glotzbach, S., Tschersich, J., Gmeiner, N., Kliem, L., \& Ficiciyan, A. (2020). Diverse seeds-shared practices: Conceptualizing seed commons. International Journal of the Commons, 14(1), 418-438. https://doi.org/10. 5334 /ijc. 1043

Sievers-Glotzbach, S., Euler, J., Frison, C., Gmeiner, N., Kliem, L., Mazé, A., \& Tschersich, J. (2021). Beyond the material: Knowledge aspects in seed commoning. Agriculture and Human Values, 38, 509-524. https://doi.org/ 10.1007/s10460-020-10167-w

Steffen, W., Richardson, K., Rockström, J., Cornell, S. E., Fetzer, I., Bennett, E. M. et al. (2015). Planetary boundaries: Guiding human development on a changing planet. Science, 347(6223), 1-15. https://doi.org/10.1126/sci ence. 1259855 
Tittonell, P. (2020). Assessing resilience and adaptability in agroecological transitions. Agricultural Systems, 184, 102862.

UNFSS. (2021). Policy options for food systems transformation in Africa一from the perspective of African universities and think tanks. Food Systems Summit Brief Prepared by Research Partners of the Scientific Group for the Food Systems Summit. Retrieved July 21, 2021, from https://sc-fss2021.org/wp-content/ uploads/2021/06/FSS_Brief_Policy_Options_Africa.pdf

UNDROP. (2019). The United Nations declaration on the rights of peasants and other people working in rural areas. United Nations. Retrieved July 19, 2021, from https://digitallibrary.un.org/record/1650694

UNEP. (2020). Preventing the next pandemic: Zoonotic diseases and how to break the chain of transmission. UNEP.

WEF. (2018). Innovation with a purpose: The role of technology innovation in accelerating food systems transformation. World Economic Forum.

White, R. J., \& Williams, C. C. (2014). Anarchist economic practices in a 'capitalist' society: Some implications for organisation and the future of work. Ephemera: Theory \& Politics in Organization, 14(4), 951-975.

Wright, J. (Ed.). (2021). Subtle agroecologies: Farming with the hidden half of nature. CRC Press.

Open Access This chapter is licensed under the terms of the Creative Commons Attribution 4.0 International License (http://creativecommons.org/licenses/ by $/ 4.0 /)$, which permits use, sharing, adaptation, distribution and reproduction in any medium or format, as long as you give appropriate credit to the original author(s) and the source, provide a link to the Creative Commons license and indicate if changes were made.

The images or other third party material in this chapter are included in the chapter's Creative Commons license, unless indicated otherwise in a credit line to the material. If material is not included in the chapter's Creative Commons license and your intended use is not permitted by statutory regulation or exceeds the permitted use, you will need to obtain permission directly from the copyright holder.

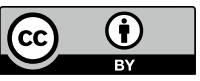

